\title{
Clinical applications of PD-L1 bioassays for cancer immunotherapy
}

\author{
Delong Liu ${ }^{1 *} \mathbb{D}$, Shuhang Wang ${ }^{2}$ and Wendy Bindeman ${ }^{3}$
}

\begin{abstract}
Programmed death ligand 1 (PD-L1) has emerged as a biomarker that can help to predict responses to immunotherapies targeted against PD-L1 and its receptor (PD-1). Companion tests for evaluating PD-L1 expression as a biomarker of response have been developed for many cancer immunotherapy agents. These assays use a variety of detection platforms at different levels (protein, mRNA), employ diverse biopsy and surgical samples, and have disparate positivity cutoff points and scoring systems, all of which complicate the standardization of clinical decision-making. This review summarizes the current understanding and ongoing investigations regarding PD-L1 expression as a potential biomarker for clinical outcomes of anti-PD-1/PD-L1 immunotherapy.
\end{abstract}

\section{Background}

Novel therapeutics targeting immune checkpoints are leading to a fast and profound paradigm shift in cancer therapy [1-3]. Durable responses to agents targeting programmed cell death-1 protein receptor (PD-1) and the ligand (PD-L1) have been observed in lung cancer as well as a variety of cancer types [4-10]. PD-L1 expression varies due to the dynamic tumor microenvironment [11-15]. No consensus has been reached on whether PD-L1 expression can serve as a reliable biomarker for patient selection in all cancer types. The assessment for PD-L1 expression is becoming routine for many cancer specimens, though how to employ the results remains a clinical challenge. This article reviews existing data of PD-L1 expression status and its predictive and prognostic role in lung cancer and makes recommendations for improving clinical interpretations.

\section{Bioassays for PD-L1 expression}

A companion diagnostic is necessary for the safe and efficacious use of a corresponding drug or biological product, whereas a complementary diagnostic identifies, though not essential, a biomarker that can assist in the risk/benefit assessment for a subset of patients who respond to the corresponding drug differentially [16, 17]. Currently, the US Food and Drug Administration (FDA)

\footnotetext{
* Correspondence: DELONG_LIU@NYMC.EDU

'Department of Oncology, The first Affiliated Hospital of Zhengzhou

University, Zhengzhou 450052, China

Full list of author information is available at the end of the article
}

has approved four immunohistochemistry (IHC)-based assays using diagnostic monoclonal antibodies, 22C3, 28-8, SP142, and SP263, to detect PD-L1 expression and aid in clinical applications of corresponding drugs (Table 1) [18-20]. 22C3 is the mouse hybridoma clone 22C3 monoclonal antibody (IgG1k) against the extracellular domain of human PD-L1 (Phe19-Thr239) [21]. In Western blotting, the 22C3 antibody labels a $40-\mathrm{kDa}$ protein band which corresponds to the recombinant human PD-L1 protein. 28-8 is a hybridoma clone generated after immunization of rabbits with the extracellular domain of human PD-L1 (Phe19-Thr239) [22]. This clone was screened by $\mathrm{IHC}$ using control cell lines with or without expression of huPD-L1 or huPD-L2 and human normal and tumor specimens with and without PD-L1 expression. The stable transfectant monoclonal anti-PDL1 clone 28-8 was produced for the PD-L1 IHC assay.

Notably, PD-L1 IHC 22C3 pharmDx and IHC 28-8 pharmDx are the first two FDA-approved assay systems for qualitative detection of PD-L1 protein in formalinfixed, paraffin-embedded (FFPE) tissue. The level of PDL1 protein expression is determined by using tumor proportion score (TPS) [22, 23]. The TPS score is the percentage of tumor cells showing partial or complete membrane staining at any intensity. Positive PD-L1 expression is defined as TPS $\geq 1 \%$, and a specimen is considered to have high PD-L1 expression if TPS $\geq 50 \%$.

The third FDA-approved antibody, SP142, is a rabbit monoclonal antibody against PD-L1 [24, 25]. This antibody has been validated and approved for use in the 
Table 1 PD-L1 immunohistochemistry assays for clinical application

\begin{tabular}{lllll}
\hline Agent & Nivolumab & Pembrolizumab & Atezolizumab & Durvalumab \\
\hline Antibody & $28-8$ & $22 \mathrm{C} 3$ & SP142 & SP263 \\
Isotype and host species & Rabbit lgG & Mouse lgG & Rabbit lgG & Rabbit lgG \\
Binding site & Extracellular & Extracellular & Intracellular & Intracellular \\
Cell scored & Tumor cell & Tumor cell & Tumor cell & Tumor cell \\
& & Tumor stroma cell & 1,5 , or $\geq 10 \%$ & \\
Cutoffs & 1,5, or $\geq 10 \%$ & $\geq 50 \%$ tumor cell & & \\
\hline
\end{tabular}

complementary assay kit, Ventana PD-L1 (SP142), to detect PD-L1 expression and guide clinical therapy with atezolizumab for advanced urothelial carcinoma and non-small cell lung cancer (NSCLC) [26-29]. The complementary assay considers PD-L1 expression levels (level 1,2 , or 3 ) in both tumor cells (TC; $1 / 2 / 3$ ) and immune cells (IC; $1 / 2 / 3$ ) for positivity. Various combinations of TC and IC expression levels were used to define positivity (cutoff values) in the clinical trials [27, 30-32].

The fourth PD-L1 antibody, SP263, was just approved as a complementary diagnostic for durvalumab. SP263 is a rabbit anti-human PD-L1 monoclonal antibody directed against the cytoplasmic region of human PD-L1 [33] that has been optimized and validated for use with FFPE NSCLC and HNSCC tissue samples. The antibody SP263 is approved for qualitative detection of PD-L1 protein in FFPE NSCLC and other tissues. Clinical cutoff values have been validated in clinical trials for guiding the use of durvalumab (NCT01693562) [18, 34].

Recently, studies have also analyzed the PD-L1 expression at the genetic level. PD-L1 and PD-1 protein expression were analyzed in 94 clinical cases of small cell neuroendocrine carcinomas by IHC using two different monoclonal antibodies (5H1, E1L3N). RNA-seq was used to profile messenger RNA (mRNA) expression in 43 clinical cases. Results showed that RNA-seq yielded highly comparable results with IHC and even more PDL1-positive cases than IHC; therefore, RNA-seq is also suitable for detection of PD-L1 expression [35]. This study also showed that the carcinoma cells were negative for PD-L1 expression in all cases, and PD-L1 was detected in tumor-infiltrating macrophages and lymphocytes. Another study examined 133 cases of lung adenocarcinoma surgical samples and found that the PD-L1 expression rate was $16.5 \%$ at the mRNA level and $13.5 \%$ at the protein level [36]. These two levels are highly concordant $($ Kappa $=0.824)$, suggesting the feasibility of using mRNA level as a biomarker for PD-L1 expression. Another study analyzed DNA copy number and mRNA expression of PD-L1 in 335 patients with soft tissue sarcomas (STS) by utilizing the sarcoma data set of The Cancer Genome Altas (TCGA) and an independent cohort of untreated high-grade STS [37]. This analysis showed that PD-L1copy number and elevated mRNA expression have prognostic significance.

\section{PD-L1 expression and cutoff values}

So far, analysis of the relationship between PD-L1 expression and response to anti-PD-1/PD-L1 agents has yielded promising results. One pooled analysis summarized data from seven studies with 914 NSCLC patients [38]. Patients with TC staining $\geq 1 \%$ were considered PDL1-positive. These patients had a significantly higher objective response rate (ORR) than those with PD-L1negative tumors. Further, the PD-L1 threshold of $\geq 1 \%$ and higher positivity (5 and 50\%) has been correlated with responses in a meta-analysis [39]. The higher the PD-L1 expression in the specimens, the higher the clinical ORR to the anti-PD-1/PD-L1 agents. In another meta-analysis of 13 studies with 1979 NSCLC patients, ORR correlation with PD-L1 expression levels assayed with several antibodies (DAKO 28-8, DAKO 22C3, VENTANA SP 142) were compared. The ORR generally increased with the level of PD-L1 expression increasing from $1,5,10,25,50$ to $75 \%$ [40]. In summary, currently available data support the hypothesis that tumor PD-L1 positivity is a useful biomarker for predicting patient response to anti-PD-1/PD-L1 agents.

An ongoing challenge to the application of PD-L1 biomarker assays in clinic is that each anti-PD1/PD-L1 agent has its own companion assay. These assays have not been standardized for all the agents and therefore are not interchangeable. However, several groups have examined the degree of agreement between different methods. One large study of 493 samples compared the extent of concordance among three validated, commercially available PD-L1 IHC assays (Ventana SP263, Dako 22C3, and Dako 28-8) for NSCLC patients and found an overall percentage agreement of $>90 \%$ between assays. These assays were also consistent at multiple expression cutoffs, including $1,10,25$, and $50 \%$ tumor cell membrane staining [41]. Most recently, Gaule et al. assessed PD-L1 expression using six monoclonal antibodies (SP142, E1L3N, 9A11, SP263, 22c3, and 28-8) on a 
genetically defined PD-L1 engineered cell line array with a range of controlled protein-expressing cell lines. They found that all six antibody reagents had high levels of concordance in this IHC standardization study [42, 43]. This study further suggested that differences in PD-L1 expression in tissues as described in the previous studies were independent of the antibody used. Rather, the differences were attributed to the tumor heterogeneity, assay-, or platform-specific variables.

\section{Factors affecting bioassays for PD-L1 expression}

PD-L1 expression is commonly focal and primarily identified at the tumor-stromal interface [44] and appears to be highly heterogeneous. Additionally, PD-L1 expression detection can be limited by the size and position of the biopsy specimen and therefore provides only a snapshot of the expression status of a tumor.

One study examined PD-L1 expression with the SP142 IHC assay in both whole surgical tissue sections and matched lung biopsies from 160 patients with operable NSCLC. PD-L1 expression was assayed in both TC and IC cells. The study found that PD-L1 expression between the surgically resected and matched biopsy specimens frequently disagree with each other (overall discordance rate $=48 \%, \kappa=0.218$ [poor agreement]) [45]. The PD-L1 assay underestimated the expression from larger resected tumor specimens. The rate of discordance was inversely proportional to the number of cores obtained. Sampling error is therefore a significant issue in the detection of PD-L1, and a single biopsy specimen with few cores may not accurately reflect the PD-L1 status of a tumor. This report is contradicted by another study which retrospectively compared small biopsy samples with resected specimens from 79 NSCLC patients. This latter study found that the positivity rate of PD-L1 assessed by IHC in the biopsy samples was 38.0 versus $35.4 \%$ in the resected specimens. This group found a concordance rate of $92.4 \%$ and $\kappa$ value of 0.8366 , suggesting that there is good concordance and adequate assessment for PD-L1 expression with small samples [46]. These retrospective studies and others are limited in relatively small sample sizes [45-47].

In addition to the focal, heterogeneous expression of PD-L1 within a single lesion, separate lesions from the same patient may have different intensities and patterns of PD-L1 expression. One study performed quantitative assessment of the heterogeneity of PD-L1 expression in 49 NSCLC whole tissue sections and a corresponding tissue microarray. Two rabbit monoclonal antibodies (E1L3N and SP142) were used for both conventional IHC and quantitative immunofluorescence (QIF). Results showed that assessment of 588 serial section fields of view by QIF exhibited a discordant expression at a frequency of $25 \%$ [44].
In addition, PD-L1 expression varies among TC, IC, and immune stroma in a given patient. Using 67 fully resected, multifocal specimens from 32 NSCLC patients to assess intertumoral heterogeneity, Mansfield et al. reported that there was poor agreement of PD-L1 expression between paired lesions of 20 patients by tumor and immune cells [48]. Although expression of $\mathrm{PD}-\mathrm{L} 1$ is heterogeneous among paired independent lung cancers, this study showed that there are high levels of agreement in intrapulmonary metastasis.

PD-L1 expression in TCs and ICs were examined in a separate study which reported that PD-L1-positive TCs were negatively correlated with PD-L1-positive ICs within tumor stroma. In this analysis of 105 patients with resected stage I pulmonary squamous cell carcinoma, tumor PD-L1 expression and increased CD4+ T cell infiltrations in tumor stroma were found to be independent predictors of better overall survival [49]. Therefore, different components of tumor and immune microenvironment may play variable roles in modulation of responses to cancer immunotherapy.

The heterogeneity also exists among primary, metastatic, and transformed tumors. One study reported a case of NSCLC who was found to have also small cell lung cancer (SCLC) transformation in the lung and liver metastasis at autopsy. The PD-L1 protein was partially expressed in tumor cells with adenocarcinoma histology but not in tumor cells from SCLC transformation [50]. Another study analyzed paired untreated primary lung cancer and metastasis tissues from 98 postmortem cases by microarray to evaluate the heterogeneity of PD-L1 expression and correlated with clinicopathological features [51]. The study found that intratumoral heterogeneity in NSCLC is common (discordance rate $82 \%$ between primary and metastatic tissues), while PD-L1 expression was undetectable in both primary and metastatic SCLC tissues.

Taken together, these studies suggest that the results of PD-L1 expression assays are affected by a variety of factors, including specimen size, biopsy location, variable components of tumor and immune microenvironment, and tumor transformation. These factors should be carefully considered when employing PD-L1 as a predictive biomarker in clinical practice.

\section{Clinical implications of soluble PD-L1}

Several members of B7 family have been found to have soluble counterparts [52-54]. Using ELISA, a soluble form of PD-L1 (sPD-L1) has been detected in the sera of patients [55]. The study showed that circulating SPD-L1 in human sera is involved in modulating immune response. It has been further suggested that upregulation of SPD-L1 production is associated with tumor-inspired immune suppression and the poor prognosis [56-58]. In 
another study of 96 patients with lung cancer (85 NSCLC, 7 SCLC), sPD-L1 was detected by ELISA [59]. High sPD-L1 levels $(\geq 7.32 \mathrm{ng} / \mathrm{ml})$ were associated with poor prognosis (high vs low sPD-L1: OS 13.0 vs 20.4 months, $p=0.037$ ) in these patients [59]. It remains unclear whether sPD-L1 level has correlation with clinical response to the checkpoint inhibitor treatment. Liquid biopsy is increasingly used as a substitute of tissue sampling [60-62]. sPD-L1 deserves further investigation to see whether it can be used to guide clinical decisions on choice of immunotherapeutic agents.

\section{Conclusions}

Novel therapeutics targeting immune checkpoints are leading to a fast and profound paradigm shift in cancer therapy. PD-L1 expression is a valuable biomarker to guide clinical decisions. PD-L1 expression assays are affected by a variety of factors, including specimen size, biopsy location, variable components of tumor and immune microenvironment, and tumor transformation. These factors should be carefully considered when employing PD-L1 as a predictive biomarker in clinical practice. Future investigations should focus on standardizing detection, developing reliable methods of liquid biopsy, and developing multiparameter quantitative or semi-quantitative biomarker panels to provide clinicians a more comprehensive understanding of the tumor and immune microenvironment. Correlation of PD-L1 expression and tyrosine kinase biomarkers should also be explored [63].

\section{Abbreviations \\ FFPE: Formalin-fixed, paraffin-embedded; IC: Immune cells; \\ IHC: Immunohistochemistry; NSCLC: Non-small cell lung cancer; ORR: Objective response rate; OS: Overall survival; PD-1: Programmed death-1; PD- \\ L1: Programmed death-1 ligand; QIF: Quantitative immunofluorescence; SCLC: Small cell lung cancer; STS: Soft tissue sarcoma; TC: Tumor cells; \\ TCGA: The Cancer Genome Altas; TPS: Tumor proportion score \\ Funding \\ This project was partly supported by the The first Affiliated Hospital of Zhengzhou University, Zhengzhou, China (DL); National Natural Science Foundation of China (Grant No. 81101726 to SW); and 2016 Conquer Cancer Foundation of ASCO Long-term International Fellowship (LIFe) \#10092 (SW). SW was also a recipient of CAHON Young Investigator Award (www.cahon.org).}

\section{Availability of data and materials}

The material supporting the conclusion of this review has been included within the article.

\section{Authors' contributions \\ DL designed the study. All authors drafted the manuscript. All authors read and approved final manuscript.}

\section{Competing interests}

The authors declare that they have no competing interests.

\section{Consent for publication}

This is not applicable for this review.

Ethics approval and consent to participate

This is not applicable for this review.

\section{Publisher's Note}

Springer Nature remains neutral with regard to jurisdictional claims in published maps and institutional affiliations.

\section{Author details}

'Department of Oncology, The first Affiliated Hospital of Zhengzhou University, Zhengzhou 450052, China. ${ }^{2}$ The Key Laboratory of Carcinogenesis and Translational Research (Ministry of Education), Peking University Cancer Hospital, Beijing, China. ${ }^{3}$ Department of Immunology, Mayo Clinic, Rochester, MN 55905, USA.

Received: 15 April 2017 Accepted: 9 May 2017

Published online: 17 May 2017

\section{References}

1. Wang J, Yuan R, Song W, Sun J, Liu D, Li Z. PD-1, PD-L1 (B7-H1) and tumorsite immune modulation therapy: the historical perspective. J Hematol Oncol. 2017;10(1):34

2. Lee CK, Man J, Lord S, Links M, Gebski V, Mok T, Yang JC. Checkpoint inhibitors in metastatic EGFR-mutated non-small cell lung cancer-a metaanalysis. J Thorac Oncol. 2017;12(2):403-7.

3. Lee JY, Lee HT, Shin W, Chae J, Choi J, Kim SH, Lim H, Won Heo T, Park KY, Lee YJ, Ryu SE, Son JY, Lee JU, Heo YS. Structural basis of checkpoint blockade by monoclonal antibodies in cancer immunotherapy. Nat Commun. 2016;7:13354.

4. Brahmer JR, Tykodi SS, Chow LQ, Hwu WJ, Topalian SL, Hwu P, Drake CG, Camacho LH, Kauh J, Odunsi K, Pitot HC, Hamid O, Bhatia S, Martins R, Eaton K, Chen S, Salay TM, Alaparthy S, Grosso JF, Korman AJ, Parker SM, Agrawal S, Goldberg SM, Pardoll DM, Gupta A, Wigginton JM. Safety and activity of anti-PD-L1 antibody in patients with advanced cancer. N Engl J Med. 2012;366(26):2455-65.

5. Brahmer J, Reckamp KL, Baas P, Crino L, Eberhardt WE, Poddubskaya E, Antonia S, Pluzanski A, Vokes EE, Holgado E, Waterhouse D, Ready N, Gainor J, Aren Frontera O, Havel L, Steins M, Garassino MC, Aerts JG, Domine M, Paz-Ares L, Reck M, Baudelet C, Harbison CT, Lestini B, Spigel DR. Nivolumab versus docetaxel in advanced squamous-cell non-small-cell lung cancer. $\mathrm{N}$ Engl J Med. 2015;373(2):123-35.

6. Hsueh EC, Gorantla KC. Novel melanoma therapy. Exp Hematol Oncol. 2016;5(1):23.

7. Kaufman HL, Russell J, Hamid O, Bhatia S, Terheyden P, D'Angelo SP, Shih KC, Lebbé C, Linette GP, Milella M, Brownell I, Lewis KD, Lorch JH, Chin K, Mahnke L, von Heydebreck A, Cuillerot J-M, Nghiem P. Avelumab in patients with chemotherapy-refractory metastatic Merkel cell carcinoma: a multicentre, single-group, open-label, phase 2 trial. Lancet Oncol. 2016;17(10):1374-85.

8. Davar D, Socinski MA, Dacic S, Burns TF. Near complete response after single dose of nivolumab in patient with advanced heavily pre-treated KRAS mutant pulmonary adenocarcinoma. Exp Hematol Oncol. 2015;4:34

9. Falchi L, Sawas A, Deng C, Amengual JE, Colbourn DS, Lichtenstein EA, Khan KA, Schwartz LH, O'Connor OA. High rate of complete responses to immune checkpoint inhibitors in patients with relapsed or refractory Hodgkin lymphoma previously exposed to epigenetic therapy. J Hematol Oncol. 2016;9(1):132.

10. Dholaria B, Hammond W, Shreders A, Lou Y. Emerging therapeutic agents for lung cancer. J Hematol Oncol. 2016;9:138.

11. Lipson EJ, Sharfman WH, Drake CG, Wollner I, Taube JM, Anders RA, Xu H, Yao S, Pons A, Chen L, Pardoll DM, Brahmer JR, Topalian SL. Durable cancer regression off-treatment and effective reinduction therapy with an anti-PD-1 antibody. Clin Cancer Res. 2013;19(2):462-8.

12. Topalian SL, Hodi FS, Brahmer JR, Gettinger SN, Smith DC, McDermott DF, Powderly JD, Carvajal RD, Sosman JA, Atkins MB, Leming PD, Spigel DR, Antonia SJ, Horn L, Drake CG, Pardoll DM, Chen L, Sharfman WH, Anders RA, Taube JM, McMiller TL, Xu H, Korman AJ, Jure-Kunkel M, Agrawal S, McDonald D, Kollia GD, Gupta A, Wigginton JM, Sznol M. Safety, activity, and immune correlates of anti-PD-1 antibody in cancer. N Engl J Med. 2012;366(26):2443-54.

13. Fang X, Chen C, Xia F, Yu Z, Zhang Y, Zhang F, Gu H, Wan J, Zhang X, Weng W, Zhang CC, Chen G-Q, Liang A, Xie L, Zheng J. CD274 promotes cell cycle entry of leukemia-initiating cells through JNK/cyclin D2 signaling. J Hematol Oncol. 2016;9(1):124. 
14. Buisseret L, Garaud S, de Wind A, Van den Eynden G, Boisson A, Solinas C, GuTrantien C, Naveaux C, Lodewyckx JN, Duvillier H, Craciun L, Veys I, Larsimont D, Piccart-Gebhart M, Stagg J, Sotiriou C, Willard-Gallo K. Tumor-infiltrating lymphocyte composition, organization and PD-1/PD-L1 expression are linked in breast cancer. Oncoimmunology. 2017;6(1):e1257452.

15. Chen S, Wang RX, Liu Y, Yang WT, Shao ZM. PD-L1 expression of the residual tumor serves as a prognostic marker in local advanced breast cancer after neoadjuvant chemotherapy. Int J Cancer. 2017;140(6):1384-95.

16. Beaver JA, Tzou A, Blumenthal GM, McKee AE, Kim G, Pazdur R, Philip R. An FDA perspective on the regulatory implications of complex signatures to predict response to targeted therapies. Clin Cancer Res. 2017;23(6):1368-72.

17. Philip R, Carrington L, Chan M. US FDA perspective on challenges in codeveloping in vitro companion diagnostics and targeted cancer therapeutics. Bioanalysis. 2011;3(4):383-9.

18. Diggs LP, Hsueh EC. Utility of PD-L1 immunohistochemistry assays for predicting PD-1/PD-L1 inhibitor response. Biomarker Research. 2017;5(1):12.

19. Hirsch FR, McElhinny A, Stanforth $D$, Ranger-Moore J, Jansson M, Kulangara K, Richardson W, Towne P, Hanks D, Vennapusa B, Mistry A, Kalamegham R, Averbuch S, Novotny J, Rubin E, Emancipator K, McCaffery I, Williams JA Walker J, Longshore J, Tsao MS, Kerr KM. PD-L1 immunohistochemistry assays for lung cancer: results from phase 1 of the blueprint PD-L1 IHC assay comparison project. J Thorac Oncol. 2017;12(2):208-22.

20. Kerr KM, Tsao MS, Nicholson AG, Yatabe Y, Wistuba II, Hirsch FR, Committee IP. Programmed death-ligand 1 immunohistochemistry in lung cancer: in what state is this art? J Thorac Oncol. 2015;10(7):985-9.

21. Tumeh $P C$, Harview CL, Yearley JH, Shintaku IP, Taylor EJ, Robert L, Chmielowski B, Spasic M, Henry G, Ciobanu V, West AN, Carmona M, Kivork C, Seja E, Cherry G, Gutierrez AJ, Grogan TR, Mateus C, Tomasic G, Glaspy JA, Emerson RO, Robins H, Pierce RH, Elashoff DA, Robert C, Ribas A. PD-1 blockade induces responses by inhibiting adaptive immune resistance. Nature. 2014;515(7528):568-71.

22. Phillips T, Simmons P, Inzunza HD, Cogswell J, Novotny Jr J, Taylor C, Zhang $X$. Development of an automated PD-L1 immunohistochemistry (IHC) assay for non-small cell lung cancer. Appl Immunohistochem Mol Morphol. 2015;23(8):541-9.

23. Dolled-Filhart M, Roach C, Toland G, Stanforth D, Jansson M, Lubiniecki GM, Ponto G, Emancipator K. Development of a companion diagnostic for pembrolizumab in non-small cell lung cancer using immunohistochemistry for programmed death ligand-1. Arch Pathol Lab Med. 2016;140(11):1243-9.

24. Boyd ZS, Smith D, Baker B, Vennapusa B, Koeppen H, Kowanetz M, Mariathasan S, Bruey J-M, Mackey H, Fine G, Mocci S, Hegde P, Williams JA, McCaffery I. Abstract B001: development of a PD-L1 companion diagnostic IHC assay (SP142) for atezolizumab. Cancer Immunol Res. 2016;4(1 Supplement):B001.

25. Schats KA, Van Vre EA, De Schepper S, Boeckx C, Schrijvers DM, Waelput W Fransen E, Vanden Bempt I, Neyns B, De Meester I, Kockx MM. Validated programmed cell death ligand 1 immunohistochemistry assays (E1L3N and SP142) reveal similar immune cell staining patterns in melanoma when using the same sensitive detection system. Histopathology. 2017;70(2):253-63.

26. Balar AV, Galsky MD, Rosenberg JE, Powles T, Petrylak DP, Bellmunt J, Loriot Y, Necchi A, Hoffman-Censits J, Perez-Gracia JL, Dawson NA, van der Heijden MS, Dreicer R, Srinivas S, Retz MM, Joseph RW, Drakaki A, Vaishampayan UN, Sridhar SS, Quinn DI, Duran I, Shaffer DR, Eigl BJ, Grivas PD, Yu EY, Li S, Kadel III EE, Boyd Z, Bourgon R, Hegde PS, et al. Atezolizumab as first-line treatment in cisplatin-ineligible patients with locally advanced and metastatic urothelial carcinoma: a single-arm, multicentre, phase 2 trial. Lancet. 2017;389(10064):67-76.

27. Rittmeyer A, Barlesi F, Waterkamp D, Park K, Ciardiello F, von Pawel J, Gadgeel SM, Hida T, Kowalski DM, Dols MC, Cortinovis DL, Leach J, Polikoff J, Barrios C, Kabbinavar F, Frontera OA, De Marinis F, Turna H, Lee JS, Ballinger M, Kowanetz M, He P, Chen DS, Sandler A, Gandara DR, Group OAKS. Atezolizumab versus docetaxel in patients with previously treated non-small-cell lung cancer (OAK): a phase 3, open-label, multicentre randomised controlled trial. Lancet. 2017;389(10066):255-65.

28. Sidaway P. Bladder cancer: atezolizumab: an alternative to cisplatin? Nat Rev Urol. 2017;14(2):67

29. Sidaway P. Urological cancer: atezolizumab: an alternative to cisplatin? Nat Rev Clin Oncol. 2017;14(3):139.

30. McDermott DF, Sosman JA, Sznol M, Massard C, Gordon MS, Hamid O, Powderly JD, Infante JR, Fasso M, Wang W, Zou W, Hegde PS, Fine GD, Powles T. Atezolizumab, an anti-programmed death-ligand 1 antibody, in metastatic renal cell carcinoma: long-term safety, clinical activity, and immune correlates from a phase la study. J Clin Oncol. 2016;34(8):833-42.

31. Mizugaki H, Yamamoto N, Murakami H, Kenmotsu H, Fujiwara Y, Ishida Y, Kawakami T, Takahashi T. Phase I dose-finding study of monotherapy with atezolizumab, an engineered immunoglobulin monoclonal antibody targeting PD-L1, in Japanese patients with advanced solid tumors. Invest New Drugs. 2016;34(5):596-603.

32. Rosenberg JE, Hoffman-Censits J, Powles T, van der Heijden MS, Balar AV, Necchi A, Dawson N, O'Donnell PH, Balmanoukian A, Loriot Y, Srinivas S, Retz MM, Grivas P, Joseph RW, Galsky MD, Fleming MT, Petrylak DP, PerezGracia JL, Burris HA, Castellano D, Canil C, Bellmunt J, Bajorin D, Nickles D, Bourgon R, Frampton GM, Cui N, Mariathasan S, Abidoye O, Fine GD, et al. Atezolizumab in patients with locally advanced and metastatic urothelial carcinoma who have progressed following treatment with platinum-based chemotherapy: a single-arm, multicentre, phase 2 trial. Lancet. 2016. 387(10031):1909-20.

33. Rebelatto MC, Midha A, Mistry A, Sabalos C, Schechter N, Li X, Jin X, Steele KE, Robbins PB, Blake-Haskins JA, Walker J. Development of a programmed cell death ligand-1 immunohistochemical assay validated for analysis of non-small cell lung cancer and head and neck squamous cell carcinoma. Diagn Pathol. 2016;11(1):95.

34. Massard C, Gordon MS, Sharma S, Rafii S, Wainberg ZA, Luke J, Curiel TJ, Colon-Otero G, Hamid O, Sanborn RE, O'Donnell PH, Drakaki A, Tan W, Kurland JF, Rebelatto MC, Jin X, Blake-Haskins JA, Gupta A, Segal NH. Safety and efficacy of durvalumab (MED|4736), an anti-programmed cell death ligand-1 immune checkpoint inhibitor, in patients with advanced urothelial bladder cancer. J Clin Oncol. 2016;34(26):3119-25.

35. Schultheis AM, Scheel AH, Ozretic L, George J, Thomas RK, Hagemann T, Zander T, Wolf J, Buettner R. PD-L1 expression in small cell neuroendocrine carcinomas. Eur J Cancer. 2015:51(3):421-6.

36. Wu S, Shi X, Sun J, Liu Y, Luo Y, Liang Z, Wang J, Zeng X. The significance of programmed cell death ligand 1 expression in resected lung adenocarcinoma. Oncotarget. 2017, 8:10.18632/oncotarget.14851.

37. Budczies J, Mechtersheimer G, Denkert C, Klauschen F, Mughal SS, Chudasama P, Bockmayr M, Johrens K, Endris V, Lier A, Lasitschka F, Penzel R, Dietel M, Brors B, Groschel S, Glimm H, Schirmacher P, Renner M, Frohling S, Stenzinger A. PD-L1 (CD274) copy number gain, expression, and immune cell infiltration as candidate predictors for response to immune checkpoint inhibitors in soft-tissue sarcoma. Oncoimmunology. 2017;6(3):e1279777.

38. Passiglia F, Bronte G, Bazan V, Natoli C, Rizzo S, Galvano A, Listi A, Cicero G, Rolfo C, Santini D, Russo A. PD-L1 expression as predictive biomarker in patients with NSCLC: a pooled analysis. Oncotarget. 2016;7(15):19738-47.

39. Abdel-Rahman O. Correlation between PD-L1 expression and outcome of NSCLC patients treated with anti-PD-1/PD-L1 agents: a meta-analysis. Crit Rev Oncol Hematol. 2016;101:75-85.

40. Aguiar Jr PN, Santoro IL, Tadokoro H, de Lima Lopes G, Filardi BA, Oliveira P, Mountzios G, de Mello RA. The role of PD-L1 expression as a predictive biomarker in advanced non-small-cell lung cancer: a network meta-analysis. Immunotherapy. 2016;8(4):479-88.

41. Ratcliffe MJ, Sharpe A, Midha A, Barker C, Scott M, Scorer P, Al-Masri H, Rebelatto M, Walker J. Agreement between programmed cell death ligand-1 diagnostic assays across multiple protein expression cut-offs in non-small cell lung cancer. Clin Cancer Res. 2017, 23:10.1158/1078-0432.CCR-1116-2375.

42. Gaule P, Smithy JW, Toki M, Rehman J, Patell-Socha F, Cougot D, Collin P, Morrill P, Neumeister $V$, Rimm DL. A quantitative comparison of antibodies to programmed cell death 1 ligand 1. JAMA Oncol. 2017;3(2):256-9.

43. Smith J, Robida MD, Acosta K, Vennapusa B, Mistry A, Martin G, Yates A, Hnatyszyn HJ. Quantitative and qualitative characterization of two PD-L1 clones: SP263 and E1L3N. Diagn Pathol. 2016;11(1):44.

44. McLaughlin J, Han G, Schalper KA, Carvajal-Hausdorf D, Pelekanou V, Rehman J, Velcheti V, Herbst R, LoRusso P, Rimm DL. Quantitative assessment of the heterogeneity of PD-L1 expression in non-small-cell lung cancer. JAMA Oncol. 2016;2(1):46-54.

45. Ilie M, Long-Mira E, Bence C, Butori C, Lassalle S, Bouhlel L, Fazzalari L, Zahaf K, Lalvee S, Washetine K, Mouroux J, Venissac N, Poudenx M, Otto J, Sabourin JC, Marquette $\mathrm{CH}$, Hofman V, Hofman P. Comparative study of the PD-L1 status between surgically resected specimens and matched biopsies of NSCLC patients reveal major discordances: a potential issue for anti-PDL1 therapeutic strategies. Ann Oncol. 2016;27(1):147-53.

46. Kitazono S, Fujiwara Y, Tsuta K, Utsumi H, Kanda S, Horinouchi H, Nokihara H, Yamamoto N, Sasada S, Watanabe S, Asamura H, Tamura T, Ohe Y. 
Reliability of small biopsy samples compared with resected specimens for the determination of programmed death-ligand 1 expression in non-smallcell lung cancer. Clin Lung Cancer. 2015;16(5):385-90.

47. Konishi J, Yamazaki K, Azuma M, Kinoshita I, Dosaka-Akita H, Nishimura M. B7-H1 expression on non-small cell lung cancer cells and its relationship with tumor-infiltrating lymphocytes and their PD-1 expression. Clin Cancer Res. 2004;10(15):5094-100.

48. Mansfield AS, Murphy SJ, Peikert T, Yi ES, Vasmatzis G, Wigle DA, Aubry MC Heterogeneity of programmed cell death ligand 1 expression in multifocal lung cancer. Clin Cancer Res. 2016;22(9):2177-82.

49. Yang CY, Lin MW, Chang YL, Wu CT, Yang PC. Programmed cell deathligand 1 expression is associated with a favourable immune microenvironment and better overall survival in stage I pulmonary squamous cell carcinoma. Eur J Cancer. 2016;57:91-103.

50. Suda K, Murakami I, Yu H, Kim J, Ellison K, Rivard CJ, Mitsudomi T, Hirsch FR. Heterogeneity in immune marker expression after acquisition of resistance to EGFR kinase inhibitors: analysis of a case with small cell lung cancer transformation. J Thorac Oncol. 2017, 12:10.1016/j.jtho.2017.1002.1002.

51. Pinato DJ, Shiner RJ, White SD, Black JR, Trivedi P, Stebbing J, Sharma R, Mauri FA. Intra-tumoral heterogeneity in the expression of programmeddeath (PD) ligands in isogeneic primary and metastatic lung cancer: implications for immunotherapy. Oncoimmunology. 2016;5(9):e1213934.

52. Oaks MK, Hallett KM. Cutting edge: a soluble form of CTLA-4 in patients with autoimmune thyroid disease. J Immunol. 2000;164(10):5015-8.

53. Oaks MK, Hallett KM, Penwell RT, Stauber EC, Warren SJ, Tector AJ. A native soluble form of CTLA-4. Cell Immunol. 2000;201(2):144-53.

54. Jeannin P, Magistrelli G, Aubry JP, Caron G, Gauchat JF, Renno T, Herbault N, Goetsch L, Blaecke A, Dietrich PY, Bonnefoy JY, Delneste Y. Soluble CD86 is a costimulatory molecule for human T lymphocytes. Immunity. 2000;13(3):303-12.

55. Chen Y, Wang Q, Shi B, Xu P, Hu Z, Bai L, Zhang X. Development of a sandwich ELISA for evaluating soluble PD-L1 (CD274) in human sera of different ages as well as supernatants of PD-L1+ cell lines. Cytokine. 2011;56(2):231-8.

56. Frigola X, Inman BA, Lohse CM, Krco CJ, Cheville JC, Thompson RH, Leibovich B, Blute ML, Dong H, Kwon ED. Identification of a soluble form of B7-H1 that retains immunosuppressive activity and is associated with aggressive renal cell carcinoma. Clin Cancer Res. 2011;17(7):1915-23.

57. Rossille D, Gressier M, Damotte D, Maucort-Boulch D, Pangault C, Semana G, Le Gouill S, Haioun C, Tarte K, Lamy T, Milpied N, Fest T, Groupe Ouest-Est des Leucemies et Autres Maladies du S, Groupe Ouest-Est des Leucemies et Autres Maladies du S. High level of soluble programmed cell death ligand 1 in blood impacts overall survival in aggressive diffuse large B-Cell lymphoma: results from a French multicenter clinical trial. Leukemia. 2014;28(12):2367-75

58. Zhang J, Gao J, Li Y, Nie J, Dai L, Hu W, Chen X, Han J, Ma X, Tian G, Wu D, Shen L, Fang J. Circulating PD-L1 in NSCLC patients and the correlation between the level of PD-L1 expression and the clinical characteristics. Thorac Cancer. 2015;6(4):534-8

59. Okuma Y, Hosomi Y, Nakahara Y, Watanabe K, Sagawa Y, Homma S. High plasma levels of soluble programmed cell death ligand 1 are prognostic for reduced survival in advanced lung cancer. Lung Cancer. 2017;104:1-6.

60. Sun W, Yuan X, Tian Y, Wu H, Xu H, Hu G, Wu K. Non-invasive approaches to monitor EGFR-TKI treatment in non-small-cell lung cancer. J Hematol Oncol. 2015:8:95

61. Leong SM, Tan KM, Chua HW, Tan D, Fareda D, Osmany S, Li M-H, Tucker S, Koay ES. Sampling circulating tumor cells for clinical benefits: how frequent? J Hematol Oncol. 2015;8(1):75.

62. Zhou Q, Yang J-J, Chen Z-H, Zhang X-C, Yan H-H, Xu C-R, Su J, Chen H-J, Tu $\mathrm{H}-\mathrm{Y}$, Zhong W-Z, Yang X-N, Wu Y-L. Serial cfDNA assessment of response and resistance to EGFR-TKI for patients with EGFR-L858R mutant lung cancer from a prospective clinical trial. J Hematol Oncol. 2016;9:86.

63. Rangachari D, VanderLaan PA, Shea M, Le X, Huberman MS, Kobayashi SS, Costa DB. Correlation between classic driver oncogene mutations in EGFR, ALK, or ROS1 and 22C3-PD-L1 250\% expression in lung adenocarcinoma. J Thorac Oncol. 2017, 12:10.1016/j.jtho.2016.1012.1026.

\section{Submit your next manuscript to BioMed Central and we will help you at every step:}

- We accept pre-submission inquiries

- Our selector tool helps you to find the most relevant journal

- We provide round the clock customer support

- Convenient online submission

- Thorough peer review

- Inclusion in PubMed and all major indexing services

- Maximum visibility for your research

Submit your manuscript at www.biomedcentral.com/submit 